\title{
Two Types of Procedural Dissatisfaction with Institutions: Lessons from Faculty Senate Reform*
}

\author{
Edward L. Lascher Jr., California State University, Sacramento
}

In their seminal work on public attitudes toward national government institutions, John R. Hibbing and Elizabeth Theiss-Morse emphasized how perception of decision-making processes colors evaluation of policy-making bodies. Why do people especially tend to dislike what Congress does? Hibbing and TheissMorse concluded, in part, that it is because conflict-laden legislative decisions are made in view of the public-and most people don't like what they see. In a characteristically blunt passage, they wrote:

\section{A surprising number of people, it seems, dislike being exposed to processes endemic to democratic government. ... People do not wish to see uncertainty, conflicting opinions, long debate, competing interests, confusion, bargaining, and compromised, imperfect solu- tions. They want government to do its job quickly and efficiently, sans conflict and sans fuss. In short, they often seek a patently unrealistic form of democracy. $(1995,147)$}

I applaud Hibbing and TheissMorse for focusing attention on how the policy-making process largely determines people's assessment of political institutions. However, I believe understanding dissatisfaction with institutions requires distinguish-

Edward L. Lascher Jr., is an associate professor in the Graduate Program in Public Policy and Administration at CSUS. He served on the ad hoc Faculty Governance Committee and is currently vice chair of the faculty senate. He is the author of The Politics of Automobile Insurance Reform, as well as articles and book chapters about such topics as legislative decision making, direct democracy, political careers, and policy communities. ing between two types of procedures: intrinsic procedures that, if at all alterable, can only be modified with major structural change (e.g., constitutional revision eliminating the separation of powers) and internal rules for conducting business. The distinction is important because there is reason to think that while intrinsic procedures largely draw the attention of outsiders, internal rules are the principal measures of institutional effectiveness used by insiders. The latter strongly influence the evaluations of insiders (i.e., decisionmakers within the institution itself).

As Hibbing and Theiss-Morse (1995, chap. 8 ; 1996) noted, changing outsiders' evaluations of institutions may require educating constituents to be more realistic about the procedural attributes of democratic governance. Conversely, tinkering with institutional rules may pay large dividends in terms of insiders' satisfaction.

These points were underscored for me by a recent effort to reform my campus' faculty senate. While the faculty senate at California State University, Sacramento (CSUS) is hardly an institution of momentous importance, I believe the striking nature of the causes of-and cures for-dissatisfaction with that body may be of broader interest to political scientists. After briefly describing the context for the reform efforts, I will offer evidence indicating that

- Contrary to what might have been anticipated, insiders were actually more disenchanted with the operation of the faculty senate than were outsiders;

- Despite the fact that the impetus for reform was a concern by some insiders that the senate was being inadequately consulted, closer observation showed that much of the disenchantment within the body was traceable to how business was conducted; and

- Reform of the rules for conducting business led to much greater insider satisfaction.

These findings come from surveys of faculty in general and faculty senators in particular, asking them how they viewed the body before and after a series of procedural changes. I conclude this article by making linkages to literature about reforms of other institutions.

\section{Context for this Study}

California State University, Sacramento is the seventh largest campus in a 23-campus public university system. Located in a rapidly growing urban area, CSUS serves about 24,000 students, about $80 \%$ of whom are undergraduates. The university has about 800 full-time and 600 part- time faculty members spread over seven colleges. The CSUS campus may be familiar to many readers as the site of the 2000 Olympic track and field trials.

CSUS operates under a system of "shared governance" widely used in higher education across the country (Gilmour 1991). Under this model, final campus decision-making authority is in the hands of the university president, but that individual takes advice from an elected faculty body (commonly known as an academic senate or faculty senate because of its quasi-legislative characteristics); the expectation being that the president will regularly defer to 


\section{TABLE 1}

Summary of Written Surveys Conducted by the Ad Hoc Faculty Governance Committee

\begin{tabular}{|c|c|c|c|c|}
\hline & Timing & Universe & $\begin{array}{l}\text { Number of } \\
\text { Responses }\end{array}$ & Questions \\
\hline $\begin{array}{l}\text { Faculty } \\
\text { Survey }\end{array}$ & $\begin{array}{l}\text { Spring } \\
1998\end{array}$ & $\begin{array}{l}\text { All } \\
\text { Faculty }\end{array}$ & 371 & $\begin{array}{l}\text { Opinions of senate; } \\
\text { support for reforms }\end{array}$ \\
\hline $\begin{array}{l}\text { Senate } \\
\text { Survey } 1\end{array}$ & $\begin{array}{l}\text { Summer } \\
1998\end{array}$ & $\begin{array}{l}\text { Faculty } \\
\text { Senators }\end{array}$ & 48 & $\begin{array}{l}\text { Opinions of senate and } \\
\text { specifics of senate } \\
\text { procedure; reform views }\end{array}$ \\
\hline $\begin{array}{l}\text { Senate } \\
\text { Survey } 2\end{array}$ & $\begin{array}{l}\text { Spring } \\
1999\end{array}$ & $\begin{array}{l}\text { Faculty } \\
\text { Senators }\end{array}$ & 30 & $\begin{array}{l}\text { Views of reformed } \\
\text { senate }\end{array}$ \\
\hline
\end{tabular}

the body's duly enacted recommendations. In practice, the extent of such deference varies greatly across campuses (see Lee 1991). At CSUS, this system is formalized in a constitution approved by the faculty and by the president.

As of the spring of 1998, the CSUS Faculty Senate consisted of 64 voting members representing each of the campus academic departments/programs as well as such special units as the library professional staff. A small number of $e x$ officio, nonvoting members also sat in the senate, representing such groups as the student government. The senate met about every two weeks, with all meetings open to anyone wishing to attend. An elected Executive Committee, headed by the senate chair, exercised some influence over the agenda. Most of the issues that came to the senate floor were first considered by one or more standing committees. Campus administration representatives regularly participated in the meetings of the full senate, Executive Committee, and senate committees, although administrators had no formal standing in these bodies. Examples of issues addressed by the 1997-98 senate included guidelines for sabbaticals, faculty merit pay, and grading practices.

Meetings of the CSUS Faculty Senate were governed by a set of loose rules adopted by the body itself. The rules specified no limits on the length of remarks or numbers of speakers, and did not distinguish between items for discussion and those for action. While the senate operated under agendas widely circulated prior to meetings, the agendas could be, and often were, altered at the meetings themselves.

As had happened at other colleges and universities (Scott 1996), tensions between faculty and administration officials increased following perceived instances in which the campus administration had circumvented the senate when making decisions. Indeed, the precipitating events for the efforts to reform CSUS governance were the introduction of two proposals by vocal senators dissatisfied with the protection of faculty prerogatives. The first called for scrapping the departmental representation system in favor of at-large elections by the colleges. The proponent claimed such a system would allow the senate to act with more authority. The second proposal, made by a former senate chair, called upon faculty to stage a symbolic "strike" to protest reallocation of funds absent prior senate committee consultation and general administration disregard for the faculty voice.

Ultimately, the senate opted not to accept either recommendation. Instead, the body created an ad hoc committee to study specific ways to improve faculty governance and report back to the full senate by the fall of 1998. The ad hoc committee met for several months before issuing a report in October containing its findings and recommendations. Most important for my purposes here, the report contains striking evidence of dissatisfaction with senate procedures, as well as extensive recommendations for procedural modifications.

Before I discuss the specific findings of the CSUS study, I should note that the inherent characteristics of academic senates seem to create a high potential for dissatisfaction (see Lee 1991). The meaningfulness of actions taken by such bodies is constantly open to question, given that final decision-making authority rests with the administration, although administrators may have strong incentives to defer to senates for such reasons as legitimacy and convenience (see Birnbaum 1991; Lee 1991). Consequently, many may view senates as "talking shops," producing little of substance. Furthermore, universities are notoriously decentralized institutions in which attempts to advance cross-departmental policy often prompt suspicion. Prolonged debate may be required to reach even moderate consensus. In short, it should not be surprising to find many faculty members (and others) who are upset with their senates.

\section{Data and Findings}

For information on how the CSUS Faculty Senate was viewed before and after the reform effort, I rely on three written surveys conducted by the ad hoc Faculty Governance Committee: a survey of all CSUS faculty on senate-related issues conducted in the late spring of 1998; a prereform survey of current faculty senators conducted shortly after the all-faculty questionnaire was administered; and a postreform survey of current faculty senators conducted in the late spring of 1999. The total numbers of responses to these surveys were 371,48 , and 30 , respectively (see Table 1$){ }^{1}$

The most unexpected finding from the first survey was that those with experience serving on the senate were, if anything, more dissatisfied with the performance of that body than were faculty as a whole. Table 2 summarizes the responses of all faculty to a question about how well the senate represented their interests. Fully $64 \%$ of those without senate experience thought that body effectively represented faculty interests, while only $39 \%$ of those with such experience did so. Moreover, 
TABLE 2 Opinions about Senate Effectiveness in Representing
Faculty Interests

\begin{tabular}{lcc}
\hline & $\begin{array}{c}\text { Senate Service } \\
(\mathrm{n}=87)\end{array}$ & $\begin{array}{c}\text { No Senate Service } \\
(\mathrm{n}=112)\end{array}$ \\
\hline $\begin{array}{l}\text { Indicated senate does } \\
\text { effectively represent faculty }\end{array}$ & $39 \%$ & $64 \%$ \\
$\begin{array}{l}\text { Indicated senate does not } \\
\text { effectively represent faculty }\end{array}$ & $61 \%$ & $36 \%$ \\
\hline$\chi^{2}=12.5 ; p<.001 \quad$ Cramer's V $=.32$ & \\
Source: Survey of CSUS faculty, spring 1998 &
\end{tabular}

this difference remained when controlling for rank, years on campus, and full-time/part-time status.

Clearly, greater familiarity with the senate did not produce greater satisfaction.

A follow-up survey of only faculty senators indicated strongly that representatives were most dissatisfied with how senate meetings were conducted. Nearly one in three faculty senators disagreed strongly or somewhat with the following statement: "Senate meetings are run in a satisfactory manner." Respondents were more likely to check phrases offering negative evaluations, especially with respect to domination of the senate by a few individuals and poor use of time, than they were to check most of the positive evaluations (e.g., "valued by participants").

Interestingly, despite the fact that a proposal to move to at-large elec- tions had been one of the factors prompting the reform effort, support for such a proposal among survey respondents (both senators and faculty as a whole) was vanishingly small. Almost nine out of ten respondents to the survey of the entire faculty supported electing senators by department. There was virtually no evidence that dissatisfaction with the representation system drove dissatisfaction with the Faculty Senate.

Indeed, despite the variety of concerns about the role the Faculty Senate played in faculty governance that had prompted the reform effort, the notable thing about the survey results was the extent to which expressions of dissatisfaction centered on internal procedural issues. Among those serving on the senate in 1998, the most common response to an open-ended question about needed changes were recommenda-

\section{TABLE 3 \\ Characterizing Senate Meetings, Before and After Procedural Changes}

\begin{tabular}{lcc}
\hline \multicolumn{1}{c}{ Phrase } & $\begin{array}{c}\text { Percent Checking Phrase } \\
\text { in 1998 }\end{array}$ & $\begin{array}{l}\text { Percent Checking Phrase } \\
\text { in 1999 }\end{array}$ \\
& $\begin{array}{l}\text { (44 checked 1 or more) } \\
\text { (28 checked 1 or more) }\end{array}$ \\
\hline Dominated by a few & 89 & 32 \\
Poor use of time & 50 & 7 \\
Too little follow up & 34 & 11 \\
Disliked by participants & 32 & 11 \\
Loosely organized & 21 & 14 \\
Valued by participants & 18 & 46 \\
Tightly organized & 9 & 50 \\
Disorganized & 7 & 54 \\
Action-oriented & 7 & 57 \\
Good use of time & 5 & 4 \\
Little discussion & 2 & 1999 \\
\hline Sources: Surveys of faculty senators, summer 1998 and spring &
\end{tabular}

tions that meetings be more tightly structured and that a few very vocal individuals be reined in. The following comments were typical.

- My recommendations: less talk, more action; and limit the number of times and length of time a senator can speak to an issue (too much "grand standing" by a few senators).

- Discourage grandstanding and unnecessary verbosity!

- Senate chair and Executive Committee need a vision, a broad focus or goal, a sense of priority issues rather than hitting whatever comes up.... Meetings must be more focused and efficient, with less wasted time, more involvement of the parliamentarian to keep it moving, and less involvement of those who take on the parliamentarian and in general dominate.

In response to evidence of this kind, the senate adopted a series of changes on a trial basis for the spring semester of 1999. The modifications were enacted primarily to improve the flow of senate business, prevent unanticipated changes in the agenda, and curb the ability of a few to dominate discussions. Among the most important changes were creating a "first reading" (discussion only) and "second reading" (action) calendar, allowing the Executive Committee to prioritize agenda items, setting limits on the allowable lengths of remarks, and making it more difficult to reorder the agenda.

Did these changes make a difference? The findings from the second survey of senators suggests they did. At the end of the 1999 spring semester, very large majorities expressed approval of all of the modifications. Even recognizing that there may be a cognitive bias toward expressing such approval, given that the senators themselves had adopted the changes, it is significant that survey respondents characterized the senate in very different terms than had survey respondents in the prior year. As can be seen by comparing the first and second data columns of Table 3, the portion of respondents who characterized the senate as "dominated by a few" fell by nearly two-thirds from what it had been in 
1998. Also, the portion that characterized the senate as making "poor use of time" fell by over four-fifths, while the portion that characterized senate meetings as "action-oriented" was over seven times higher than it had been the previous year. Findings from a spring 2000 survey with some of the same questions indicate that senators continued to evaluate the body much more positively than they did in $1998 .{ }^{2}$

\section{Conclusion: Individualism and Institutional Rules Revisited}

Political journalist Alan Ehrenhalt (1982), in a classic article about how U.S. senators themselves viewed their institution, stressed the frustration caused by excessive individual-

\section{Notes}

* I wish to thank Tom Krabacher for helpful comments on earlier drafts.

1. A complete summary of the survey find- ism, which was encouraged by floor rules that were highly deferential toward the maverick legislator. Senators groused to him about how "obstructionists" tied the body in knots. Yet, Uslaner (1993) subsequently argued that the widely observed decline in congressional comity was most likely the result of a general decline in civility in society, rather than, as some had argued, the consequence of any internal rules changes. This work suggests that rules reform likely would be ineffective in coping with excessive individualism.

While I realize that the CSUS faculty senate can hardly be compared to the national legislature in terms of significance, there are a great many lesser political institutions in American society, and much to indicate that there is extensive dissatisfaction with these institutions as well. The CSUS experience suggests a fairly optimistic conclusion about the potential for internal reform to improve insiders' evaluations of such institutions. Yes, when it comes to assessing institutions, "It's the process, stupid" (Hibbing and Theiss-Morse 1995, 145). Yes, insiders may be especially frustrated by rules that defer too much to "lone rangers" and prevent things from getting done. But, also, yes, changing those rules can make institutional participants significantly more satisfied. Even if the larger society needs to be reeducated about how messily democratic processes work, tinkering can make a difference to insiders. ings can be found on the CSUS Faculty Senate's web site (www.csus.edu/acse/tffg).

2 . The 2000 survey was mainly devoted to other topics, such as the senate's agenda for the upcoming academic year.

\section{References}

Birnbaum, Robert. 1991. “The Latent Organizational Functions of the Academic Senate: Why Senates Do Not Work but Will Not Go Away." In Faculty in Governance: The Role of Senates and Joint Committees in Academic Decisions, ed. Robert Birnbaum. San Francisco: Jossey-Bass.

Ehrenhalt, Alan. 1982. "In the Senate of the "80s, Team Spirit Has Given Way to the Rule of Individuals." Congressional Quarterly Weekly Report, September 4, 2175-82.

Gilmour, Joseph E. 1991. "Participative Governance Bodies in Higher Education: Re- port of a National Study." In Faculty in Governance: The Role of Senates and Joint Committees in Academic Decisions, ed. Robert Birnbaum. San Francisco: JosseyBass.

Hibbing, John R., and Elizabeth TheissMorse. 1995. Congress as Public Enemy: Public Attitudes Toward American Political Institutions. Cambridge: Cambridge University Press.

-. 1996. "Civics Is Not Enough: Teaching Barbarics in K-12." PS: Political Science and Politics 29(March): 57-62.
Lee, Barbara. 1991. "Campus Leaders and Campus Senates." In Faculty in Governance: The Role of Senates and Joint Committees in Academic Decisions, ed. Robert Birnbaum. San Francisco: Jossey-Bass.

Scott, Joanna Vecchiarelli. 1996. "The Strange Death of Faculty Governance." PS: Political Science and Politics 29(December): 724-26.

Uslaner, Eric M. 1993. The Decline of Comity in Congress. Ann Arbor: University of Michigan Press. 